\title{
ERROR ANALYSIS ON THE USE OF PAST TENSE IN NARRATIVE TEXT
}

\author{
by \\ Novita Hasianna Manurung ${ }^{1}$ (novitahasianna@gmail.com) \\ Irma Khoirot Daulay, S.S., M.Hum. ${ }^{2}$ (irmaemhum@gmail.com)
}

\begin{abstract}
The purpose of this study is to analyze students' mistakes about using past tense in Narrative texts based on problems that make students feel confused about using past tense in their writing, especially Narrative texts. The research method is descriptive qualitative. The subject of research researchers chose grade 8 (2019/2020) at SMP Pasundan Medan. The results showed that the researcher found four types of errors: omission, additions, misinformation, misordering. Then, the researchers found the highest error made by students was misinformation with a percentage of 53\%. This problem is influenced by students feeling confused to understand the simple past because they do not know the meaning and difference between regular verbs and irregular verbs. Therefore, students claim that they rarely practice writing paragraphs.
\end{abstract}

Key Words: error analysis, past tense, narrative text.

A. INTRODUCTION

Learning English must have four skills namely listening, speaking, reading and writing. And many schools in Indonesia implement a new system in English to implement global change. And many schools have used the 2013 curriculum implemented by the government to create universities and capable students who have high competitiveness to develop the country. In this study, the researcher focused on examining error analyzes about the use of simple past in narrative texts and this research is related to students' writing skills because writing skills are different from other skills in the process of learning English.

Writing is the activity of sending ideas and packaging ideas into written forms that can be understood by others. Writing skills are an important role in improving communicative language. Writing is also a skill that can show mastery of other aspects. However, most eighth grade students of Medan Pasundan Middle School still have difficulty writing good texts in English and have low grades in writing.

The problem is caused in several aspects, namely 1) because English is a foreign language and not an everyday language in communication 2) students do not have enough practice in writing texts, determining main ideas, using the right words, and arranging sentences. Therefore, students need to master the structure of English, must have enough vocabulary, also know the spelling of words to write correct sentences and arrange them into good paragraphs. 3) the technique used by the teacher does not support students' motivation to write paragraphs. 
In addition, tenses are part of the grammar and the function of tenses is to explain the accidents in the story that happened. Thus, students must understand the tenses section in writing paragraphs or essays. One of the tenses is Simple Past, these tenses explain accidents that happened in the past.

As an example:

Last holiday, my family and I visited Tarutung for a picnic. We arrived at Tarutung at 4 am and we were very tired at that time. Then, we went to the hotel to take a shower and prepare our trip. We have planned to visit the SalibKasih Temple as the first place. Moreover, Tarutung has a beautiful view that makes us happy to spend time. Based on preliminary observations with an English teacher and a number of students at Pasundan Medan Middle School. It was found that eighth graders felt confused to understand the simple past because they did not know the meaning of the words. Other students also said that they were still confused about the difference between regular verbs and irregular verbs or they did not know the change from verb one to verb two.

Narrative text is a text that explains about telling stories and telling chronologically what happened. The purpose of this text is to entertain the reader and this text can also bring the reader into the story. This text usually tells about fairy tales, legends, myths, faitytale. The similarity between research from several experts and in this study is the analysis of errors from the simple past use in writing narrative texts but the researcher focuses on analyzing errors based on the surface structure of the taxonomy by Dulay and Krashen. They are neglect, additions, misinformation, and misreading. Based on the explanation above, the writer is interested in conducting a study entitled "Error Analysis On The Use Of Past Tense In Narrative Text in Class VIII Pasundan Middle School Medan".

Based on the above background we can set the questions for this research. The questions are: 1) What mistakes have students made in writing narrative texts?

\section{B. METHOD}

This research method is content analysis. This is used to describe student mistakes. First, the writer gives a narrative writing test to students in the class. Second, the writer collects student tests then analyzes them by evaluating the percentage of students in form and in the use of simple past tense. Finally, the authors publish data about what mistakes most students do. It's important to focus on the problem to avoid. The author only emphasizes the mistakes of students in using Simple Past Tense in writing narration. To collect data, the authors used an English writing test. The author provides a test to determine the frequency of errors in using the Simple Past Tense in the Narrative text. This test is a narrative paragraph writing test. In this section, to analyze students 'answers in the form of simple past tense, the author discusses the error items as follows:

1. The author focuses on students' mistakes in using simple past tense in narrative texts made by students in the given test.

2. The author collects and classifies errors based on the type. Then the author verifies the frequency of errors made by students. 
3. The author then uses descriptive analysis techniques (percentage) to analyze the data.

In this study, the authors provide tests that are not difficult and not easy, and the authors consider these tests valid. The author approves a test that discusses the teacher used to teach English grammar in class VIII.

The Formula:

$\mathbf{P}=\mathbf{F} \mathbf{X} \frac{100 \%}{\mathbf{N}}$

Notes:

$\mathbf{P}=$ Percentages

$F=$ Frequency

$\mathbf{N}=$ Number of cases (total of frequency)

Findings and Discussion

\section{Findings}

\begin{tabular}{|c|c|c|c|c|}
\hline \multirow{2}{*}{$\begin{array}{c}\text { Stude } \\
\text { nts }\end{array}$} & \multicolumn{4}{|c|}{ Types of Errors } \\
\cline { 2 - 5 } & Ssion & $\begin{array}{c}\text { Add } \\
\text { ition }\end{array}$ & $\begin{array}{c}\text { Misfor } \\
\text { mation }\end{array}$ & $\begin{array}{c}\text { Misor } \\
\text { dering }\end{array}$ \\
\hline Aurel & 1 & 2 & 4 & 0 \\
\hline $\begin{array}{c}\text { Chan } \\
\text { dra }\end{array}$ & 3 & 5 & 8 & 0 \\
\hline $\begin{array}{c}\text { Chels } \\
\text { ea }\end{array}$ & 2 & 2 & 4 & 0 \\
\hline $\begin{array}{c}\text { Chris } \\
\text { ty }\end{array}$ & 3 & 2 & 9 & 0 \\
\hline Clara & 4 & 3 & 5 & 0 \\
\hline Faldo & 3 & 2 & 4 & 0 \\
\hline $\begin{array}{c}\text { Kriss } \\
\text { ando }\end{array}$ & 2 & 2 & 4 & 0 \\
\hline Laila & 2 & 2 & 11 & 0 \\
\hline Lilis & 2 & 2 & 7 & 1 \\
\hline $\begin{array}{c}\text { Magd } \\
\text { alena }\end{array}$ & 1 & 4 & 6 & 0 \\
\hline $\begin{array}{c}\text { Mari } \\
\text { o }\end{array}$ & 3 & 2 & 7 & 1 \\
\hline $\begin{array}{c}\text { Mikh } \\
\text { a }\end{array}$ & 0 & 2 & 7 & 1 \\
\hline
\end{tabular}

\begin{tabular}{|c|c|c|c|c|}
\hline Musa & 3 & 3 & 6 & 0 \\
\hline $\begin{array}{c}\text { Nabil } \\
\text { a }\end{array}$ & 4 & 3 & 8 & 2 \\
\hline Selin & 5 & 4 & 7 & 2 \\
\hline $\begin{array}{c}\text { Yosaf } \\
\text { at }\end{array}$ & 2 & 4 & 5 & 1 \\
\hline $\begin{array}{c}\text { Yulit } \\
\text { a }\end{array}$ & 2 & 1 & 6 & 0 \\
\hline $\begin{array}{c}\text { Juml } \\
\text { ah }\end{array}$ & 42 & 45 & 108 & 8 \\
\hline Total & \multicolumn{4}{|c|}{203} \\
\hline
\end{tabular}

Percentage Of Student's Errors:

$\mathbf{P}=\mathbf{F} \mathbf{X} \frac{100 \%}{\mathbf{N}}$

Notes:

$\mathrm{P}=$ Persentages

$\mathrm{F}=$ Frequency

$\mathrm{N}=$ Number of cases (total of frequensi)

\section{a. Omission}

$P=\frac{42}{203} \times 100 \%=20 \%$

b. Addition

$P=\frac{45}{203} \times 100 \%=22 \%$

c. Misformation

$P=\frac{108}{203} \times 100 \%=53 \%$

d. Misordering

$P=\frac{8}{203} \times 100 \%=3,9 \%$

\section{RESULT AND DISCUSSION}

After the researcher observed the English learning process between the English teacher and VIII students, the researcher collected the data and concluded that if VIII students almost entirely made mistakes in their writing, especially making Narrative texts. This problem was discovered by researchers based on the results of errors analyzed with observational checklists. There are many factors that cause errors in their writing. Based on data 
collection conducted by researchers, students feel confused when they translate between Indonesian into English or more precisely.

Not only that, students can not about the structure of English especially using tenses when they write Narrative texts. so they don't pay attention to the tension in their writing. In addition, factors that are influenced by English teachers can occur, for example English teachers do not use the media to explain narrative text material and some students do not pay attention to the teacher's explanation and many more causes of errors that have been explained by researchers with a list of questions. Therefore, Error analysis is important because this method can help the English teacher find the next medium or technique for teaching writing and help students if they find difficulties in making paragraphs. Error analysis is a tool to help researchers examine grammatical errors made by students mainly using tenses in narrative texts.

Based on previous research used by researchers from Wati (2011), researchers found that the results of Wati (2011) Analysis of errors are important to describe what types of mistakes students make because each student has different errors when they make paragraphs and how students can learn from their mistakes as English teachers Error analysis is important to improve their methods when they teach. Then, based on Syarif (2014) researchers find Error analysis is a language learning process for analyzing, observing, interpreting and classifying learner errors to give us an indication in learning processes especially in the past that are sustainable.

In addition, researchers found that the dominant errors in Wati (2011) were neglect and misodering with a percentage of $28.9 \%$. Then, the dominant error after negligence is misinformation and the last is addition. The findings of this study from Wati (2011) differ from these findings because the dominant error is a misinformation. This problem is influenced by different factors between the findings of researchers and Wati's findings, the dominant error in Wati (2011) is influenced by English teachers who are unaware of the mistakes that make students write and he does not check their students' writing. In addition, Wati's research object was a ninth grade student. The English teacher in Wati's research only focused on the student's test strategy and did not explain more about the form of words. This factor causes students in Wati (2011) to make neglect and misordering.

Meanwhile, researchers found the dominant error in Sharif (2014) was misinformation with $58 \%$. The researchers' findings between the researcher and Sharif (2014) are the same but the highest error after misinformation is negligence. The possible error factor is the level class used as a different object. Syarif (2014) uses the tenth value as an object. Therefore, the factors that make mistakes are different from the findings of this study. Sharif (2014) found if factors were made.

The mistake of students is that they use present tense as a language feature in narrative text. According to Hourani (2008: 18) "Error analysis is an important source of 
information for teachers. It provides information about students 'mistakes which in turn helps teachers to correct students' mistakes and also increase the effectiveness of their teaching ".

Correlation between the findings of researchers and previous research, there is a difference in the importance of error analysis that this method can help English teachers find the next media or technique to teach writing and help students if they find difficulties in making paragraphs. This theory is suspected by previous research that illustrates the analysis of errors has an important role to find solutions by teachers about what they need to do next in explaining the material, especially writing paragraphs and for error analysis students can use correction material from their assignments. Therefore, if they can write, they don't make the same mistakes.

Based on data collection and discussion in the previous chapter, the researchers concluded that VIII students made mistakes in their writing. From the data collection and analysis results of the researcher Narrative texts made by students, most of them make mistakes in the simple continuous structure of the past and past. They do not pay attention to the verb changes in the past and the past, this statement is supported by data that shows $53 \%$ of students make mistakes in the misinformation section. Then, students also make mistakes in other types of mistakes.
They like $22 \%$ of students make mistakes in addition, $20 \%$ omission, $3.9 \%$ misordering. From these data, we can find out that VIII students have problems regarding the use of tenses in narrative texts. They are confused if using the word forms applied to paragraphs.

\section{REFERENCE}

Utama, Syatrya and Listianingsih. (2019) Panduan Praktis Menulis Artikel. Jakarta: Penerbit PRENADAMEDIA GROUP.

Anwar, S. (2014). An Error Analysis On The Use of Simple Past In Students Narrative Writing (Thesis, State Islamic University Syarif Hidayatullah, Jakarta). Retrieved from:http: repository.uinjkt.ac.id/.../Saipul\%20A nwar\%20108014000076,Accessed on November, 13th 2016.

Khasanah. (2015). The Implementation of 2013 Curicullum By The English Teacher And Its Barries (Thesis, Universitas Negeri Islam Walisongo, Semarang ). Retrieved from http: // eprints.walisongo.ac.id/view/year/201 5.default.html, Accessed on November, 15th 2016.

Nurhadi. (2019) Handbook of Writing. Jakarta: penerbit PT. Bumi Aksara. 